\title{
ANALYSIS OF CHANGES IN ISTANBUL CITY INDEX VALUES WITH HIDDEN MARKOV MODEL
}

\author{
İSTANBUL ŞEHIIR ENDEKS DEĞERLERINDE MEYDANA GELEN \\ DEĞİŞIMLERIN SAKLI MARKOV MODELİ İLE ANALIZZI
}

Öyküm Esra AŞKIN

\begin{abstract}
City indexes are not only a significant indicator of regional development but also a very useful guide for decision makers interested in investment to a specific region. Different city indexes have been calculated by İstanbul Stock Exchange (ISE) in order to reflect the financial performances of cities. The main purpose of this study is to predict the future behaviors of İstanbul city index which has the highest share of stocks being traded on ISE. To achieve this purpose, an important pattern recognition technique that produces reliable estimates, Hidden Markov model (HMM), is suggested. The model is constructed with four exogenous factors such as exchange rate, interest rate, money supply and consumer price index and the validity of model is shown by one-, two - and three-months ahead successful prediction results.
\end{abstract}

Keywords: City Indexes, İstanbul City Index, Hidden Markov Model, Future Predictions, Index Behavior.

JEL Classification: G1, B21, C13, C51

Özet

Şehir endeksleri, bölgesel kalkınmanın önemli bir göstergesi olmasının yanı sıra belirli bir bölgeye yapılacak yatırımla ilgilenen karar vericiler için oldukça yararlı bir rehberdir. Şehirlerin finansal performanslarını yansıtmak amacıyla Borsa İstanbul (BİST) tarafından farklı şehir endeksleri hesaplanmaktadır. Bu çalışmanın amacı BİST’de işlem gören en çok hisse senedine sahip olan İstanbul şehir endeksinin gelecekteki davranışlarını tahmin etmektir. Bu amaca ulaşmak için güvenilir tahminler üreten ve önemli bir örüntü tanıma tekniği olan Saklı Markov Modeli (SMM) önerilmiştir. Model, döviz kuru, faiz oranı, para arzı ve tüketici fiyat endeksi olmak üzere dört endojen faktörle kurulmuş ve modelin geçerliliği bir-, iki - ve üç-aylık ileriye dönük başarılı tahmin sonuçlarıyla gösterilmiştir.

Anahtar Kelimeler: Şehir Endeksleri, İstanbul Şehir Endeksi, Saklı Markov Modeli, Gelecek Tahmini, Endeks davranıșı.

JEL Sinıflandırması: G1, B21, C13, C51

* Asst. Prof. Dr. Yildiz Technical University, Department of Statistics, oykumesra@gmail.com 


\section{Introduction}

Indexes are important investment tools used as an indicator of the performance of stock markets. As mentioned by Markowitz, investment in market portfolio is more preferable than investment in a single asset in terms of risk minimization. ${ }^{1} \mathrm{~A}$ regional index can be seen as a portfolio which reflects a specific characteristics of a region. Different regional indexes have been calculated since the beginning of 90's for different aims. Case-Shiller Home Price Index is a national home price index published by Standard and Poor's for the purpose of reflecting real estate market dynamics in United States metropolitan regions. The Global Cities Index was first calculated in 2008 and allows ranking of sixty six cities from the scale of one to ten. During the calculation of this index, five weighted information are used obtained by experts: business activity, human capital, information change, cultural experience and political engagement. Besides dimension of financial and growth, also important indexes are calculated in order to show human development and environmental level such as The Well-Being Index and The Green City Index. ${ }^{2}$ According to the dimension, a specific problem can be monitored and investigated on a micro scale by using regional indexes.

By inspiring the city indexes calculated for different regions in all over the world, ISE announced in 2009 that it had started to calculate nine city indexes with the purpose of reflecting financial performance of the relevant city. In order to be a helpful guide for investors on deciding to construction of investments based on a reliable regional development indicator, twelve city indexes are calculated at the present time. These indexes are; Adana (XSADA), Ankara (XSANK), Antalya (XSANT), Balıkesir (XSBAL), Bursa (XSBUR), Denizli (XSDNZ), İstanbul (XSIST), İzmir (XSIZM), Kayseri (XSKAY), Kocaeli (XSKOC), Konya (XSKON) and Tekirdağ (XSTKR).

ISE city indexes display the price and return performances of companies whose registered offices or main production premises are located in the same city. To start calculating a city index, minimum five companies' stocks must be traded on the exchange and provide following criteria: ${ }^{3}$

1. Minimum half of production must takes place in the same city for manufacturing companies

2. Minimum half of operating income must be derived in the same city for service companies. Communication \& construction companies and holdings are not included in computing a city index.

3. The registered offices must located in the same city if minimum half of production or operating income does not derived in the same city.

4. Except companies mentioned above, banks, insurance companies, financial leasing companies, factoring companies, investment/real estate/venture capital investment trusts, brokerage

1 Bayrakdaroğlu, A., Tepeli, Y. (2018). BİST Şehir Endekslerinin Risk-Getiri Analizi Üzerine Bir İnceleme, Muhasebe ve Finansman Dergisi, 80: 147-160.

2 López-Ruiz, V.-R. et al. (2014). Knowledge-City Index Construction: An Intellectual Capital Perspective, Expert Systems with Applications, 41(12): 5560-5572.

3 İstanbul Stock Exchange web page, http://www.borsaistanbul.com, (Access Date: 29.01.2019) 
houses and companies that operate in retail trade sector are not included in computing city indexes.

Each city index is a portfolio formed by at least five companies' stocks providing one of the above criteria. Investigating and comparing their performances might be a useful guide in a micro level, especially in these days when the regional development strategy is being more crucial issue. ${ }^{4}$ As seen in Table 1, there are 203 stocks within the scope of city indexes traded on the exchange. Except Balıkesir, Denizli and Konya, all other nine city indexes started to be calculated on January 2009 with the starting value of $28.864,07$. The starting value was chosen as the closing value of ISE-100 index on January 2, 2009.

Table 1: Properties of City Indexes

\begin{tabular}{|l|c|c|c|}
\hline & $\begin{array}{c}\text { Number of } \\
\text { Companies }\end{array}$ & $\begin{array}{c}\text { INDEX Starting } \\
\text { Date }\end{array}$ & $\begin{array}{c}\text { Index Starting } \\
\text { Value }\end{array}$ \\
\hline XSADA & 6 & $01 / 02 / 2009$ & $28.864,07$ \\
\hline XSANK & 16 & $01 / 02 / 2009$ & $28.864,07$ \\
\hline XSANT & 4 & $01 / 02 / 2009$ & $28.864,07$ \\
\hline XSBAL & 4 & $05 / 13 / 2012$ & $66.535,13$ \\
\hline XSBUR & 15 & $01 / 02 / 2009$ & $28.864,07$ \\
\hline XSDNZ & 4 & $07 / 06 / 2012$ & $61.972,14$ \\
\hline XSIST & 94 & $01 / 02 / 2009$ & $28.864,07$ \\
\hline XSIZM & 6 & $01 / 02 / 2009$ & $28.864,07$ \\
\hline XSKAY & 19 & $01 / 02 / 2009$ & $28.864,07$ \\
\hline XSKOC & 5 & $01 / 02 / 2009$ & $28.864,07$ \\
\hline XSKON & 3 & $12 / 05 / 2012$ & $75.522,65$ \\
\hline XSTKR & & $01 / 02 / 2009$ & $28.864,07$ \\
\hline TOTAL & \multicolumn{3}{|l}{} \\
\hline
\end{tabular}

The first study that focused on city indexes and their basic statistical properties was done by Bayramoğlu and Pekkaya. ${ }^{5}$ They noted that city indexes which formed in the area of finance is an important indicator for the frame of regional development. Besides, they noticed that these indexes are efficient tools for investors in deciding their investment strategy on a determined city. The performance comparisons can be done and obtained information which monitor the current situation of that city can help investors for correct decision related with investment.

When the entire literature of city indexes are examined, it is seen that there are few studies and these are generally focus on modeling the returns with autoregressive conditional heteroskedasticity (ARCH) model and its variations such as GARCH, E-GARCH and T-GARCH. In this way, volatility can be measured and the best fitted model can be selected by using different model

4 Aşkın Ö.E., Büyüklü A.H. (2014). Testing the Calendar Anomalies for BIST City Indexes with Symmetric and Asymmetric GARCH Models, İktisat İsletme ve Finans, 29: 59-82.

5 Bayramoğlu, M.F., Pekkaya, M. (2010). İMKB Tarafından Hesaplanan Endekslerde Yeni Gelişmeler ve İMKB Şehir Endeksleri, Muhasebe ve Finansman Dergisi, 45: 200-215. 
selection criteria (e.g., AIC/SIC information criteria, log-likelihood values). However, it is very important to forecast future trends of these indexes' behaviors in order to overcome challenges of investment decision. Due to the chaotic nature of time series data, future predictions should be performed by carefully with an accurate methodology. HMM is one of the superior method that gives successful and reliable prediction results for the time series data. For this purpose, in this study, an HMM is suggested as the method of making predictions for city indexes for the first time. İstanbul city is selected and ISE-XSIST returns are taken as the data set of constructed model. The reason of this selection is that 94 companies regarding XSIST city index are being traded on ISE and the biggest number of companies belongs to this city index when compared with other city indexes.

In future prediction of a stock market value, using some important factors changed by the current and previous information in the market plays a vital role. As in all stock returns, ISE city indexes are affected by many factors and these factors can be grouped in two main categories: (i) endogenous factors: factors related with company and (ii) exogenous factors: factors related with economic and political changes. Since accessing endogenous factors and getting reliable information from them are sometimes impossible, ${ }^{6}$ this study focuses on exogenous factors and their impacts in the process of constructing an HMM. Exogenous factors are determined as exchange rate, interest rate, money supply and consumer price index which are widely used effective factors on the prediction of stocks' change rate in the financial literature.

This study aims to fill the gap on the current city indexes literature by constructing an HMM and making future predictions for the İstanbul city index data. The remainder of this study is organized as follows. Section 2 provides important studies that were focused on ISE city indexes and financial asset prediction by using HMMs. Summary information about HMM methodology is provided in Section 3. Section 4 gives some description of the data sets used in this study. Data preparation process and applications are explained in Section 5. Results of one-, two - and three -months ahead predictions are discussed in Section 6. Finally, some conclusion remarks and further studies are outlined in Section 7.

\section{Literature Review}

Literature Review section is introduced under two main headings. Firstly, some important studies deal with ISE city indexes are presented. Also, methodologies applied in modeling and investigating financial performances of ISE city indexes are briefly reviewed. Secondly, studies with using HMMs as a methodology in predicting changes of any financial asset are discussed.

When the entire literature is examined, it can be clearly seen that experimental studies focused on ISE city indexes have been published few in number. After announcement of ISE about starting

6 Öz, E. (2009). İstanbul Menkul Kıymetler Borsası Üzerine Saklı Markov Modeli ile Bir Tahminleme, Ekonomik Yaklaşım, 20(72): 59-85. 
to calculation of city indexes, Bayramoğlu and Pekkaya ${ }^{7}$ investigated nine city indexes in terms of their descriptive behaviors for the period between January 2, 2009 and May 8, 2009. Besides, correlation between city indexes are calculated and interpreted. The work of Aksoy ${ }^{8}$ enables researchers to show investment behaviors of foreign investors during financial crisis period. Cities which their indexes are calculated by ISE were taken as dummy variables and included to the regression model. The regression coefficients of İstanbul, İzmir, Ankara and Tekirdağ were found positive which means that foreign investors prefer companies located in big cities in making decision of investment. Atmaca ${ }^{9}$ examined ISE city indexes with performing multivariate GARCH model in order to analyze volatility behaviors. Besides daily index returns of city indexes, the author used crude oil and exchange rate returns to construct heavy-tailed DCC-GARCH model. The results showed the evidence that crude oil series are significantly positively correlated with all city index series except Antalya. Kula and Baykut ${ }^{10}$ investigated the city indexes and their structure of volatility and regime switching by using different ARCH models for the period of 2012 to 2017. They focused on symmetric and asymmetric ARCH models and reported most appropriate models for each daily returns of city indexes. Yapraklı et al. ${ }^{11}$ considered ten city indexes between the years 2009 and 2017 and they compared the performances of estimated GARCH, EGARCH and TGARCH models. Unlike studies based on modeling returns of city indexes by using symmetric and asymmetric ARCH specifications, Bayrakdaroğlu and Tepeli ${ }^{12}$ investigated risk-return balance for the period of 2012-2017. Their findings help investors to better understanding in investment decision by showing comparisons of high and low returns of city indexes. Besides this, Çakır ${ }^{13}$ dealt with some performance measurements which consider total and systematic risk for the purpose of evaluating financial performances of city indexes. Results indicated that while the highest performance is observed in the city of Tekirdağ, lowest performance is belong to İstanbul city index.

As it is shown above, different traditional methodologies have been performed for ISE city indexes in the aim of modeling their returns, exhibiting their volatility behaviors and putting forth their financial performances for investors. But still there is lack of research evaluating city indexes, especially in predicting their movement behaviors. Stock market prediction is an important phoneme in financial research. Due to the fact that traditional methods have some limitations,

7 Bayramoğlu and Pekkaya, 2010, 200.

8 Aksoy, M. (2013). İstanbul Menkul Kıymetler Borsası’nda Finansal Kriz Döneminde Yabancı Yatırımcıların Hisse Senedi Tercihlerinin Analizi, İÜ Siyasal Bilgiler Fakültesi Dergisi, 48: 135-150.

9 Atmaca, V.D. (2018). BİST Şehir Endeksleri Oynaklığının DCC-GARCH Model ile Analizi, Yönetim Bilimleri Dergisi, 16(31): 287-308.

10 Kula, V., Baykut, E. (2018). BİST Şehir Endekslerinin Volatilite Yapıları ve Rejim Değişimlerinin Analizi, Muhasebe ve Finans İncelemeleri Dergisi, 1(1): 38-59.

11 Yapraklı et al. (2018). BIST Şehir Endekslerinde Oynaklığın Ölçülmesi: Alternatif Ekonometrik Modellerin Karşılaştırmalı Olarak İncelenmesi, Finans Politik \& Ekonomik Yorumlar, 639: 67-86.

12 Bayrakdaroğlu, A., Tepeli, Y. (2018). BİST Şehir Endekslerinin Risk-Getiri Analizi Üzerine Bir İnceleme, Muhasebe ve Finansman Dergisi, 80: 147-160.

13 Çakır, Z. (2016). Şehir Endekslerinin Finansal Performanslarının Ölçülmesi ve Değerlendirilmesi, (Yayımlanmamış Yüksek Lisans Tezi), Hitit Üniversitesi, Sosyal Bilimler Enstitüsü, Çorum. 
such as in the cases of non-stationary and seasonality, numerous flexible and robust methods have been attracted much attention (e.g., machine learning algorithms, fuzzy systems). One of these superior methods, namely HMM, are generally used in the fields of speech recognition, DNA sequencing and image processing and models within the scope of Hidden Markov have been started to apply datasets in order to make stock price forecasting in recent years. According to Hassan and Nath, ${ }^{14}$ due to unpredictable, complex, non-linear and volatile behaviors of time series, stock market forecasting needed to be done with some intelligent prediction models such as HMM. Determining hidden states and calculating their probabilities are important challenges in building an HMM especially when the data set is time dependent. ${ }^{15}$ To overcome this challenges, a novel approach was introduced by Hassan and Nath ${ }^{16}$ and one-day forecasts of stock prices was achieved by using HMM with four factors (prices of opening, high, low and closing). For the same purpose, new hybrid approaches were demonstrated by combining HMM and various machine learning techniques such as fuzzy logic, genetic algorithm and artificial neural network. ${ }^{17},{ }^{18}$ Angelis and Paas ${ }^{19}$ applied an HMM with using seven hidden states to the weekly returns of S\&P 500 index and compare the results with constructed GARCH model to the same dataset. It was shown that HMM gave the best performance on forecasting when compared with GARCH specification. Nootyaskool and Choengtong ${ }^{20}$ used dollar index, interest rate, inflation rate and economic growth as exogenous factors and constructed an HMM model in order to make a prediction for foreign exchange rate.

When studies used HMM as a forecasting method for Turkish stock market are examined, it is seen that limited number of studies are available. The first study was carried out by Can and Öz. ${ }^{21}$ To get appropriate number of hidden states, they used an empirical knowledge as mentioned in the study of Duan et al. ${ }^{22}$ Hidden states were exchange rate, interest rate and money supply and the purpose was estimating U.S. dollar rate for the year 2008 by HMMs. The data set in the period between 1992 and 2007 was collected. Their findings reveal that estimated dollar rate changes with HMMs have highly accurate results. In the study of Öz, ${ }^{23}$ ISE-100 index which

14 Hassan, M.R., Nath, B. (2005). Stock Market Forecasting Using Hidden Markov Model: A New Approach, 5th International Conference on Intelligent System Design and Application, Poland, 8-10 September.

15 Duan, J. et al. (2009). A Prediction Algorithm for Time Series Based on Adaptive Model Selection, Expert Systems with Applications, 36: 1308-1314.

16 Hassan and Nath, 2005, 192.

17 Hassan, M. et al. (2007). A Fusion Model of HMM, ANN and GA for Stock Market Forecasting, Expert Systems with Applications, 33(1): 171-180.

18 Hassan, R. (2009). A Combination of Hidden Markov Model and Fuzzy Model for Stock Market Forecasting, Neurocomputing, 72: 3439-3446.

19 Angelis, L.D., Paas, L.J. (2013). A Dynamic Analysis of Stock Markets Using a Hidden Markov Model, Journal of Applied Statistics, 40(8): 1682-1700.

20 Nootyaskool, S., Choengtong, W. (2014). Hidden Markov Models Predict Foreign Exchange Rate, 14th International Symposium on Communications and Information Technologies (ISCIT), Incheon, 24-26 September.

21 Can, T., Öz, E. (2009). Saklı Markov Modelleri Kullanılarak Türkiye’de Dolar Kurundaki Değişimin İncelenmesi, İstanbul Üniversitesi İşletme Fakültesi Dergisi, 1: 1-23.

22 Duan et al., 2009, 1308.

23 Öz, 2009, 59. 
is an important financial indicator was used and the efficient estimation results were reported. Dağlığlu and Kıral ${ }^{24}$ contributed to the literature by making accurate predictions of ISE-100 index in the period between 2005 and 2017. Predictions were achieved by HMMs.

\section{Methodology}

An HMM is a successful statistical procedure for investigating future behaviors of time series data. ${ }^{25}$ In HMM, the system which is being modeled is assumed to be a Markov process with hidden states (cannot directly observable). An HMM can be defined with following 5 properties:

1. The number of states in an HMM model is denoted as $N$. A set of hidden states and the sequence of states are shown as $S$ and $S=\left\{S_{1}, S_{2}, \ldots, S_{N}\right\}$, respectively. ${ }^{26}$

2. The number of observations per state is denoted as $M$. A discrete set of observation and the sequence of observations is shown as $V$ and $V=\left\{v_{1}, v_{2}, \ldots, v_{M}\right\}$, respectively.

3. A state transition probability distribution is shown as $A=\left\{a_{i j}=P\left(q_{\mathrm{t}+1}=S_{j} \mid q_{\mathrm{t}}=S_{i}\right)\right\}$ where $1 \leq i, j \leq N, A$ is an $N \times N$ state transition probability matrix and $q_{\mathrm{t}}$ is the state in time $t$. The total of each row in $A$ should be equal to 1 . State transition probabilities are independent from observations and remain the same over time. ${ }^{27}$

4. Anobservation probabilitydistribution is shownas $B=\left\{b_{j}(k)\right\}_{\text {where }} b_{j}=P\left(v_{k}\right.$ at $\left.t \mid q_{\mathrm{t}}=S_{j}\right)$. Here $b_{j}(k)>0$ and the constraints are $1 \leq j \leq N$ and $1 \leq k \leq M$. $B$ is an $N \times M$ observation probability matrix and the total of each row in $B$ should be equal to 1 .

5. A prior state probability is shown as $\pi=\left\{\pi_{i}=P\left(q_{1}=S_{i}\right)\right\}_{\text {where }} 1 \leq i \leq N$. $\pi_{i}$ shows the probability of being in state $S_{i}$ at the beginning of a system and $\pi$ is an $N$ dimensional prior state probability distribution vector. ${ }^{28}$

The observation sequence $\mathrm{O}=\mathrm{O}_{1} \mathrm{O}_{2} \ldots \mathrm{O}_{\mathrm{T}}$ is generated with $\mathrm{N}, \mathrm{M}, \mathrm{A}, \mathrm{B}$ and $\pi$ in an HMM. Here, $T$ is the number of observations and $\mathrm{O}_{\mathrm{T}}$ is an observation from $\left\{v_{1}, v_{2}, \ldots, v_{M}\right\}$. More generally, a parameter vector of an HMM can be displayed $\lambda=(A, B, \pi)$. Following three fundamental problems can be solved by an HMM.

24 Dağlığlu, C., Kıral, G. (2018). Hisse Senedi Piyasa Fiyatlarının Saklı Markov Modeli ile Tahmin Edilmesi, Uluslararası Ekonomi ve Yenilik Dergisi, 4(1): 61-75.

25 Saul, L., Jordan, M. (1995). Boltzmann Chains and Hidden Markov Models. Adv. Neural Inf. Process. Syst., 7: 435-442.

26 Can, T., Öz, E. (2009). Marka Tercihlerine ve Tercih Nedenlerine Gizli Markov Modelinin Uygulanması, Eskişehir Osmangazi Üniversitesi Sosyal Bilimler Dergisi, 10(2): 167-185.

27 Bhar, R., Hamori, S. (2004). Hidden Markov Models Applications to Financial Economics, Netherlands: Kluwer Academiz Publishers, 16.

28 Bicego, M., Murino, V. (2004). Investigating Hidden Markov Models' Capabilities in 2D Shape Classification, IEEE Transactions On Pattern Analysis and Machine Intelligence, 26(2): 281-286. 


\subsection{Evaluation Problem}

The probability of observation sequence $\mathrm{P}(O \mid \lambda)$ is computed for a given parameter vector $\lambda=(A, B, \pi)$ and the observation sequence $0=0_{1} O_{2} \ldots O_{\mathrm{T}}$. This calculation can be done by Forward-Backward (FB) algorithm described in Rabiner. ${ }^{29}$

\subsection{Decoding Problem}

A most likely hidden state sequence $\theta=\mathrm{q}_{1} \mathrm{q}_{2} \ldots \mathrm{q}_{\mathrm{T}}$ is produced for the observation sequence $0=0_{1} O_{2} \ldots O_{\mathrm{T}}$ and the model $\lambda=(A, B, \pi)$. This process is achieved by using Viterbi Algorithm. ${ }^{30}$

\subsection{Learning Problem}

Model parameters $A, B$ and $\pi$ are optimized in order to maximize the probability of observation sequence $\mathrm{P}(O \mid \lambda)$. Different methods such as Baum-Welch algorithm, Expectation-Maximization (EM) algorithm and Gradient-based techniques can be used for this process. Baum-Welch which is an iterative method is widely used in training HMM. Unknown parameters are estimated with using probabilities calculated in FB solution process. ${ }^{31}$

\section{Data Descriptions}

This part includes some descriptions of İstanbul city index. Also, sub-states which are used in prediction process are briefly presented.

\section{1. İstanbul City Index}

İstanbul city index is a portfolio which is formed by the stocks of 94 companies providing the essential criteria determined by ISE. Table 2 shows the companies under XSIST index on sectoral basis. As it can be seen that while the sector of "Professional, Scientific and Technical Activities" has the lowest share with $1.1 \%$, the highest share is observed in the "Manufacturing" sector with $28.7 \%$. Stocks of 12 city indexes can be categorized under 11 sectors and XSIST index contains all given 11 sectors' stocks. This study uses monthly closing prices of XSIST city index from 2009 January through 2018 October. When the closing price is shown as $P_{t}$, return series obtained by using the formula $R_{t}=\log \left(P_{t} / P_{t-1}\right)$ where $t$ denotes the current month and $\mathrm{t}=(1,2, \ldots, 118)$.

29 Rabiner, 1989, $257-286$.

30 Lou, H. (1995). Implementing the Viterbi Algorithm, IEEE Signal Processing Magazine, 12(5): 42-52.

31 Vaseghi, S.V. (2007). Multimedia Signal Processing Theory and Applications in Speech, Music and Communications, England: John-Wiley \& Sons Ltd., 334. 
Table 2: Stocks Traded in XSIST

\begin{tabular}{|c|c|c|c|}
\hline Industry Groups & Stocks Code & Frequency & Valid Percent \\
\hline $\begin{array}{c}\text { Professional, Scientific and Technical } \\
\text { Activities }\end{array}$ & IDEAS & 1 & $1.1 \%$ \\
\hline $\begin{array}{c}\text { Administrative and Support Service } \\
\text { Activities }\end{array}$ & AKGUV, FLAP & 2 & $2.1 \%$ \\
\hline Renting and Business Activities & ARMDA, DGATE & 2 & $2.1 \%$ \\
\hline Electricity, Gas and Water & AKENR, AKSEN, ENJSA & 3 & $3.2 \%$ \\
\hline $\begin{array}{l}\text { Education, Health, Sports and Other } \\
\text { Social Services }\end{array}$ & BJKAS, FENER, GSRAY, MPARK & 4 & $4.3 \%$ \\
\hline $\begin{array}{c}\text { Whosale and Retail Trade, Hotels } \\
\text { and Restaurants }\end{array}$ & AVTUR, DOAS, INTEM, METUR, SELEC, TGSAS & 6 & $6.4 \%$ \\
\hline $\begin{array}{c}\text { Transportation, Communication and } \\
\text { Storage }\end{array}$ & CLEBI, GSDDE, PGSUS, RYSAS, TCELL, THYAO & 6 & $6.4 \%$ \\
\hline Construction and Public Works & $\begin{array}{l}\text { ANELE, EDIP, ENKAI, KUYAS, ORGE, SANEL, } \\
\text { TURGG, YYAPI }\end{array}$ & 8 & $8.5 \%$ \\
\hline Technology & $\begin{array}{c}\text { ARENA, DESPC, ESCOM, INDES, KFEIN, } \\
\text { KRONT, LINK, NETAŞ, PKART }\end{array}$ & 9 & $9.6 \%$ \\
\hline Financial Institutions & $\begin{array}{c}\text { AGHOL, ALARK, AVHOL, BRYAT, BOYP, DENGE, } \\
\text { DOHOL, ECZYT, ECILC, EUHOL, GLYHO, } \\
\text { GSDHO, GLRHY, SAHOL, IEYHO, IHLAS, IHYAY, } \\
\text { KCHOL, MARKA, METRO, NTHOL, TAVHL, } \\
\text { TKFEN, SISE, VERUS, YESIL }\end{array}$ & 26 & $27.7 \%$ \\
\hline Manufacturing Industry & $\begin{array}{l}\text { ADEL, AKCNS, ALCAR, AEFES, ARCLK, AYGAZ, } \\
\text { BRSAN, CCOLA, CUSAN, DAGI, DGZTE, } \\
\text { DERIM, DURDO, GOODY, GUBRF, HURGZ, } \\
\text { IHEVA, IHGZT, IZOCM, MEGAP, OLMIP, PARSN, } \\
\text { POLTK, PRZMA, TRKCM, TUCLK, TRCAS } \\
\end{array}$ & 27 & $28.7 \%$ \\
\hline Tot. Num. of Stocks Traded & XSIST & 94 & $100 \%$ \\
\hline
\end{tabular}

\subsection{Sub-States}

As mentioned in the study of Gonzales et al. ${ }^{32}$, hidden states should be well defined and constructed model with HMM should be capable of discovering hidden states. In this study, 4 exogenous factors are taken as sub-states and hidden states are created with using these substates. Sub-states are exchange rate, interest rate, money supply as were used in the study of Öz ${ }^{33}$ and consumer price index as was suggested in the study of Kara et al. ${ }^{34}$ All datasets are obtained from the Central Bank of the Republic of Turkey (CBRT) data delivery system covering the period from 2009 January through 2018 October. ${ }^{35}$

32 Gonzales, A. et al. (2005). Modeling and Forecasting Electricity Prices with Input/Output Hidden Markov Models, IEE Transactions on Power Systems, 20(1): 13-24.

33 Öz, 2009, 59.

34 Kara, Y. et al. (2011). Predicting Direction of Stock Price Index Movement Using Artificial Neural Networks and Support Vector Machines: The Sample of the İstanbul Stock Exchange, Expert Systems with Applications, 38(5): 5311-5319.

35 Central Bank of the Republic of Turkey web page, https://evds2.tcmb.gov.tr/index.php?/evds/serieMarket, (Access Date: 29.01.2019) 
Exchange rate is an important factor that affects stock prices and ISE indexes. In this study, monthly US Dollar (buying) percentage change (PC) is used as the first sub-state that affects the XSIST city index. The second sub-state is taken as interest rates and monthly up to 1 month TRY deposits PC data is used. Thirdly, money supply is selected. As it is known three indicators, M1, M2 and M3 are included in the CBRT data delivery system and M1 (Thousand TL) PC data is taken into account in this study. Finally, consumer price index of $1^{\text {st }}$ region İstanbul PC data is used as the last sub-state.

\section{Application}

Before modeling the data with HMM and then making future predictions, a set of hidden states $(S)$ is created and following two steps are applied:

Step 1: Transformation into Discrete Form: In the first step, the data set which includes return series of XSIST and PC series of 4 sub-states is transformed into discrete-valued form. As it is described in Table 3, XSIST city index return series are grouped into two categories, $\mathrm{G}_{1}$ and $\mathrm{G}_{2}$. If $R_{t}$ is greater than $R_{t-1}$, then it means return of month $t$ is increasing when compared with month $t-1$. Thus, current month's observation is labeled with $G_{1}$, otherwise it is labeled with $G_{2}$. XSIST data consisted of 118 observations, of which 64 are increasing and 54 are decreasing. Exchange rate data is also splitted into two categories, $D_{1}$ and $D_{2}$. Let $P C_{t}$ denotes the value of $P C$ of current month $t$ where $t=(1,2, \ldots, 118)$. The rule is; if $P_{t}$ is greater than 0 , it means $P C$ of month $t$ is increasing and it is labeled with $\mathrm{D}_{1}$, otherwise $\mathrm{D}_{2}$. The data set consists of 118 exchange rate PC values, of which 70 are increasing and 48 are decreasing. The same process is applied for interest rate, money supply and consumer price index PC data. The rest of analyses are performed by transformed data.

Table 3: Descriptions for Transformed Data Set

\begin{tabular}{|l|c|c|l|c|}
\hline & Increasing Symbol & $\begin{array}{c}\text { Decreasing } \\
\text { Symbol }\end{array}$ & Rule & $\begin{array}{c}\text { Total Number of } \\
\text { Increasing \& Decreasing } \\
\text { Observations }\end{array}$ \\
\hline XSIST & $G_{1}$ & $G_{2}$ & If $\mathrm{R}_{\mathrm{t}}>\mathrm{R}_{\mathrm{t}-1}$ then $G_{1}$, otherwise $G_{2}$ & $\begin{array}{c}G_{1}=64 ; \\
G_{2}=54\end{array}$ \\
\hline $\begin{array}{l}\text { Exchange } \\
\text { Rate }\end{array}$ & $D_{1}$ & $D_{2}$ & If $\mathrm{PC}_{\mathrm{t}}>0$, then $D_{1}$, otherwise $D_{2}$ & $\begin{array}{c}D_{1}=70 ; \\
D_{2}=48\end{array}$ \\
\hline Interest Rate & $F_{1}$ & $F_{2}$ & If $\mathrm{PC}_{\mathrm{t}}>0$, then $F_{1}$, otherwise $F_{2}$ & $F_{1}=62 ;$ \\
\hline $\begin{array}{l}\text { Money } \\
\text { Supply }\end{array}$ & $P_{1}$ & $P_{2}$ & If $\mathrm{PC}_{\mathrm{t}}>0$, then $P_{1}$, otherwise $P_{2}$ & $\begin{array}{l}P_{1}=82 ; \\
P_{2}=36\end{array}$ \\
\hline $\begin{array}{l}\text { Consumer } \\
\text { Price Index }\end{array}$ & $T_{1}$ & $T_{2}$ & If $\mathrm{PC}_{\mathrm{t}}>0$, then $T_{1}$, otherwise $T_{2}$ & $T_{1}=96 ;$ \\
\hline
\end{tabular}

As it is given in Table 3, there are 2 elements in each set of sub-states. For example, the set of exchange rate can be shown as $\left\{D_{1}, D_{2}\right\}$. Also, the sets of interest rate, money supply and consumer 
price index are demonstrated as $\left\{F_{1}, F_{2}\right\},\left\{P_{1}, P_{2}\right\}$ and $\left\{T_{1}, T_{2}\right\}$, respectively. It is important to underline that while the transition of elements between each other in a set is allowed, there is no transition of elements between any other set of sub-state.

Step 2: Creating Hidden States: In the second step, the sequence of hidden states is created according to number of observations and sub-states. Here we have 2 observations $\left(G_{1}\right.$ and $\left.G_{2}\right)$ which one of them could be observed and 4 sub-states so there are $4^{2}=16$ possible hidden states related with corresponding observation. Each hidden state has a unique sequence of substates. For example, $S_{1}$ is the first created hidden state and it is formed with 4 sub-states shown as $\left(D_{1}, F_{1}, P_{1}, T_{1}\right)$. Table 4 shows the sequences of sub-states for all hidden states. Despite there should be 16 hidden states, 15 different hidden states are used in modeling because sub-states $D_{2}$ $, F_{1}, P_{2}$ and $T_{2}$ are not observed simultaneously in the transformed data.

Table 4: Hidden States and Corresponding Sub-States

\begin{tabular}{|c|c|c|c|}
\hline Hidden State & Sub-States & Hidden State & Sub-States \\
\hline$S_{1}$ & $\left(D_{1}, F_{1}, P_{1}, T_{1}\right)$ & $S_{9}$ & $\left(D_{2}, F_{1}, P_{1}, T_{1}\right)$ \\
\hline$S_{2}$ & $\left(D_{1}, F_{1}, P_{1}, T_{2}\right)$ & $S_{10}$ & $\left(D_{2}, F_{1}, P_{1}, T_{2}\right)$ \\
\hline$S_{3}$ & $\left(D_{1}, F_{1}, P_{2}, T_{1}\right)$ & $S_{11}$ & $\left(D_{2}, F_{1}, P_{2}, T_{1}\right)$ \\
\hline$S_{4}$ & $\left(D_{1}, F_{1}, P_{2}, T_{2}\right)$ & Not observed & $\left(D_{2}, F_{1}, P_{2}, T_{2}\right)$ \\
\hline$S_{5}$ & $\left(D_{1}, F_{2}, P_{1}, T_{1}\right)$ & $S_{12}$ & $\left(D_{2}, F_{2}, P_{1}, T_{1}\right)$ \\
\hline$S_{6}$ & $\left(D_{1}, F_{2}, P_{1}, T_{2}\right)$ & $S_{13}$ & $\left(D_{2}, F_{2}, P_{1}, T_{2}\right)$ \\
\hline$S_{7}$ & $\left(D_{1}, F_{2}, P_{2}, T_{1}\right)$ & $S_{14}$ & $\left(D_{2}, F_{2}, P_{2}, T_{1}\right)$ \\
\hline$S_{8}$ & $\left(D_{1}, F_{2}, P_{2}, T_{2}\right)$ & $S_{15}$ & $\left(D_{2}, F_{2}, P_{2}, T_{2}\right)$ \\
\hline
\end{tabular}

A state transition probability matrix $(A)$ is obtained by using the information of hidden state in month $\mathrm{t}$ and hidden state in month $\mathrm{t}+1$ and given in Appendix 1. Here, conditional probability is used as mentioned earlier. For example, $a_{11}$ is the first element of $[A]_{15 \times 15}$ and $a_{11}=P\left(q_{t+1}=S_{1} \mid q_{t}=S_{1}\right)=0.33$ where $q_{t}$ is the state in time $t$.

An observation probability matrix $(B)$ which is given in Appendix 2 is obtained by using states and corresponding observations in the same month. The conditional probability is used as in above. For example, $b_{1}$ is the probability value in state 1 and corresponding observation $G_{1}$ in time $t$ and can be found as $b_{1}=P\left(G_{1}\right.$ at $\left.\left.t\right|_{q_{t}}=S_{1}\right)=0.7619$ where $q_{t}$ is the state in time $t$.

4 dimensional prior state probability distribution vector is taken as $\pi_{i}=\{0.25,0.25,0.25,0.25\}$ which means that each state in the beginning is equally likely to observe. 
To evaluate the performance of constructed HMM, one month ahead, two month ahead and three month ahead predictions are carried out. This process can be done by answering mainly two questions:

1. What is the probability of each element in a set of an observation or the observation sequence for a given $\lambda=(A, B, \pi)$ ?

2. What are the underlying hidden state(s) that explain the selected observation or observation sequence?

The first question is an evaluation problem and the probabilities of occurrence of observation(s) sequences are found. Observation or observation sequence with the highest probability is taken as prediction result. FB algorithm is applied in the evaluation problem. The second question is a decoding problem and Viterbi algorithm is used. The hidden states are estimated according to the related observation/observation sequence which has/have the highest probability found in evaluation problem. The third problem of HMM optimize the parameters in order to achieve higher probabilities of desired observation sequences. In this study, third problem of HMM is not handled because the purpose is prediction, not finding optimal parameters of HMM.

Transformed data set for the period between 2009 January - 2018 July is used to construct the HMM, in other words 115 of the 118 observations are used in training of the model. Rests of three observations (August, September and October 2018) are taken as testing data and forward predictions (one-, two - and three - months ahead) are made by using these observations.

\section{Results}

One-month, two-month and three months ahead prediction results are given in this part of the study.

\subsection{One-Month Ahead Prediction}

In this part, one-month ahead prediction is performed for the August, 2018. The prediction of PC of month August will be one of the elements in the set of $\left\{G_{1}, G_{2}\right\}$. Probabilities belong to $G_{1}$ and $G_{2}$ are calculated with $\mathrm{FB}$ algorithm. The observation which has the highest probability is taken as predicted observation. After determining the predicted observation, inference of the underlying hidden states is performed by Viterbi algorithm. One-month ahead prediction results are given in Table 5 .

Table 5: Results of One-month Ahead Prediction

\begin{tabular}{|c|c|c|c|c|c|}
\hline \multicolumn{3}{|c|}{ Real } & \multicolumn{3}{|c|}{ Predicted } \\
\hline Observation & State & $\begin{array}{c}\text { Sub-Hidden } \\
\text { States } \\
\end{array}$ & $\begin{array}{l}\text { Observation } \\
\text { (Probability) }\end{array}$ & State & Sub-Hidden States \\
\hline$G_{1}$ & $S_{1}$ & $S_{1}=\left(D_{1}, F_{1}, P_{1}, T_{1}\right)$ & $G_{1}=0.52 G_{2}=0.48$ & $S_{1}$ & $S_{1}=\left(D_{1}, F_{1}, P_{1}, T_{1}\right)$ \\
\hline
\end{tabular}


According to Table 5, the observation probabilities for $G_{1}$ and $G_{2}$ are found to be 0.52 and 0.48 , respectively. Since the highest probability is observed in $G_{1}$, it can be said that $G_{1}$ is the predicted observation. In other words, according to predicted observation, it is expected that the behavior of XSIST return is increasing in August when compared with July. As seen in table, the real observation is $G_{1}$, so the expectation is met. Besides, underlying hidden state of HMM is estimated as $S_{1}$. Hidden state $S_{1}$ consists of $D_{1}, F_{1}, P_{1}$ and $T_{1}$ sub-states. It is expected that the increasing behavior of XSIST in August is explained by the increasing exchange rate, interest rate, money supply and consumer price index. As it is seen in table, the real hidden state is the same as in the expectation. Thus, it can be said that one-month ahead prediction by HMM is achieved efficiently.

\subsection{Two-Months Ahead Prediction}

This part includes two-month ahead (August and September 2018) predictions given the transformed data. The prediction of PC of two months will be one of the combination of observations sequence. Probabilities that belong to $\left\{G_{1}, G_{1}\right\}\left\{G_{1}, G_{2}\right\},\left\{G_{2}, G_{1}\right\},\left\{G_{2}, G_{2}\right\}$ are found by using FB algorithm. Estimations of underlying hidden states of related observations sequence which has the highest probability (also called as predicted observations) are carried out via Viterbi algorithm. Table 6 shows the results of FB and Viterbi algorithms.

As it is seen in Table 6, observations sequence of $\left\{G_{1}, G_{1}\right\}$ has the highest probability with 0.2632 . Thus, predicted observations are taken as $G_{1}$ for August and $G_{1}$ for September. This means, it is expected that increasing XSIST returns are observed in August and September compared with returns of their previous months. The expectation is met because as seen in table, real observations are $G_{1}$ for both August and September. Besides, underlying hidden states for August and September are predicted as $S_{1}$ and $S_{1}$. In other words, it is expected that the increasing behaviors of XSIST returns in August and September are explained by the increasing exchange rate, interest rate, money supply and consumer price index. On the other hand, the real hidden states are $S_{1}$ for August and $S_{3}$ for September. While the hidden states of August is correctly estimated, estimation of September's hidden state $\left(S_{1}\right)$ is different from the real state $\left(S_{3}\right)$. Despite this, it should be note that only one sub-state (money supply) is different when sub-state sequence of expectation $\left(D_{1}, F_{1}, P_{1}, T_{1}\right)$ and sub-state sequences of real $\left(D_{1}, F_{1}, P_{2}, T_{1}\right)$ are compared.

Table 6: Results of Two-months Ahead Prediction

\begin{tabular}{|l|c|c|c|c|c|}
\hline \multicolumn{3}{|c|}{ Real } & \multicolumn{1}{c|}{ State } & Sub-Hidden States \\
\hline Observation & State & $\begin{array}{c}\text { Sub-Hidden } \\
\text { States }\end{array}$ & $\begin{array}{c}\text { Observation } \\
\text { (Probability) }\end{array}$ & \multicolumn{1}{c|}{ Predicted } \\
\hline$G_{1}, G_{1}$ & $S_{1}, S_{3}$ & $S_{1}=\left(D_{1}, F_{1}, P_{1}, T_{1}\right)$ & $G_{1}, G_{1}=0.2632$ & $S_{1}, S_{1}$ & $S_{1}=\left(D_{1}, F_{1}, P_{1}, T_{1}\right)$ \\
& & $S_{3}=\left(D_{1}, F_{1}, P_{2}, T_{1}\right)$ & $G_{1}, G_{2}=0.2568$ & & $S_{1}=\left(D_{1}, F_{1}, P_{1}, T_{1}\right)$ \\
& & & $G_{2}, G_{1}=0.2380$ & & \\
& & & $G_{2}, G_{2}=0.2420$ & & \\
\hline
\end{tabular}




\subsection{Three-Months Ahead Prediction}

In this part, three months ahead (August, September and October 2018) predictions are performed by using the same transformed data set as in above. The prediction of PC of three months will be one of the 8 combination of observations sequence given in Table 7. Probabilities of all observation sequences are found via FB algorithm. Also, inferences of underlying hidden states of related observations sequence are found by Viterbi algorithm and shown in Table 7.

Table 7: Results of Three-months Ahead Prediction

\begin{tabular}{|c|c|c|c|c|c|}
\hline \multicolumn{2}{|c|}{ Real } & \multicolumn{3}{c|}{ Predicted } \\
\hline Observation & State & $\begin{array}{c}\text { Sub-Hidden } \\
\text { States }\end{array}$ & $\begin{array}{c}\text { Observation } \\
\text { (Probability) }\end{array}$ & State & Sub-Hidden States \\
\hline$G_{1}, G_{1}, G_{2}$ & $S_{1}, S_{3} S_{11}$ & $S_{1}=\left(D_{1}, F_{1}, P_{1}, T_{1}\right)$ & $G_{1}, G_{1}, G_{1}=0.136$ & $S_{1}, S_{1}, S_{1}$ & $S_{1}=\left(D_{1}, F_{1}, P_{1}, T_{1}\right)$ \\
& & $S_{3}=\left(D_{1}, F_{1}, P_{2}, T_{1}\right)$ & $G_{1}, G_{1}, G_{2}=0.127$ & & $S_{1}=\left(D_{1}, F_{1}, P_{1}, T_{1}\right)$ \\
& & $S_{11}=\left(D_{2}, F_{1}, P_{2}, T_{1}\right)$ & $G_{1}, G_{2}, G_{1}=0.133$ & & $S_{1}=\left(D_{1}, F_{1}, P_{1}, T_{1}\right)$ \\
& & $G_{1}, G_{2}, G_{2}=0.123$ & & \\
& & & $G_{2}, G_{1}, G_{1}=0.125$ \\
& & $G_{2}, G_{1}, G_{2}=0.112$ & & \\
& & $G_{2}, G_{2}, G_{1}=0.125$ & & \\
& & & $G_{2}, G_{2}, G_{2}=0.116$ & & \\
& & &
\end{tabular}

The highest probability is found as 0.136 which belongs to the observations sequence of $\left\{G_{1}, G_{1}, G_{1}\right\}$. According to this, predicted observations are taken as $G_{1}$ for three months - August, September and October. This means, it is expected that increasing XSIST returns are observed in August, September and October when compared with previous months (July, August and September, respectively). The expectation for the months August and September is met. While the predicted observation for October is found as $G_{1}$, the real observation is $G_{2}$. This means the model predict increasing XSIST return in October compared with August. However, decreasing behavior of XSIST return is observed in the real data. Besides, underlying hidden states for three months are predicted as $S_{1}, S_{1}, S_{1}$. It is expected that the increasing behaviors of XSIST returns in three months are explained by the increasing exchange rate, interest rate, money supply and consumer price index. On the other hand, the real hidden states are $S_{1}, S_{3}$ and $S_{11}$. As in twomonths ahead prediction, in September's results, it is very important to underline that 1 sub-state (money supply) is different when expectation and real sub-states are compared. In addition to September, October's results are very close to real situation. The model correctly estimates the increasing behaviors of interest rate $\left(F_{1}\right)$ and consumer price index $T_{1}$ in August.

\section{Conclusion}

Market efficiency is an important phenomenon for the investors who aim to achieve risk minimization in the process of making investment strategy. An investment strategy is set with 
using all available information such as the financial situation of a specific region. In order to reflect the financial performance of a city, ISE has been calculated city indexes for different cities in Turkey since 2009. The financial comparability of the cities due to these indexes make them very useful guide to both researchers and investors.

Important studies have been done to in the topic of modeling the volatility behaviors of these indexes with using $\mathrm{ARCH}$ and its variations. However, monitoring future behaviors of these indexes plays a significant role in investment choice to a region under uncertainty. This study suggest an HMM to predict the behavior of İstanbul city index from the past observations.

The model is built with four exogenous factors which are exchange rate, interest rate, money supply and consumer price index for the period between 2009 January and 2018 July. Hidden states are defined by using a set of combination of 4 exogenous factors. The evaluation and decoding problems are solved via FB and Viterbi algorithm, respectively. One month ahead (for 2018 August), two month ahead (for 2018 August and September) and three month ahead (for 2018 August, September and October) predictions are carried out to evaluate the performance of suggested HMM.

Results show that constructed HMM produces $100 \%$ correct predictions for August. The increasing return behavior of XSIST can be explained through the increasing behaviors of exchange rate, interest rate, money supply and consumer price index. As in one month ahead prediction results, the model correctly estimate return behaviors of XSIST for August and September. Also, underlying hidden state for August is correctly estimated, in other words, increasing behaviors of all sub-states explain the increasing behavior of XSIST return. Besides, except sub-state of money supply, the model with exchange rate, interest rate and consumer price index well explained the increasing behaviors of XSIST compared with previous two months (August and September). In addition, when three months ahead predictions are performed, it is found that behaviors of XSIST return are correctly estimated for following two months August and September. All predicted sub-states for August are observed in August. Also, predicted substates are nearly same with real sub-states for September and October.

In HMM studies, number of past observations play a vital role in order to achieve successful predictions for future. Training process of the model use past observations and higher number of past observations increase estimation performance. The XSIST index has been calculated since 2009 January so, in this study, all available XSIST index and four exogenous factors information starts from this date in the CBRT data delivery system is used. It is worth to mention that when XSIST data set size increases as time goes by, HMM predictions will be more successful.

Future studies can be focused on other city indexes to show their future behaviors. On the other hand, 4 exogenous factors are used as the effective factors in XSIST return changes. By increasing the number of effective factors, more sensitive prediction results can be obtained. 


\section{References}

AKSOY, M. (2013). İstanbul Menkul Kıymetler Borsası’nda Finansal Kriz Döneminde Yabancı Yatırımcıların Hisse Senedi Tercihlerinin Analizi, İÜ Siyasal Bilgiler Fakültesi Dergisi, 48: 135-150.

ANGELIS, L.D., Paas, L.J. (2013). A Dynamic Analysis of Stock Markets Using a Hidden Markov Model, Journal of Applied Statistics, 40(8): 1682-1700.

ATMACA, V.D. (2018). BİST Şehir Endeksleri Oynaklığının DCC-GARCH Model ile Analizi, Yönetim Bilimleri Dergisi, 16(31): 287-308.

AYAZ, O., Alp, S. (2018). Saklı Markov Modeli Kullanılarak İstanbul'daki Üniversite Öğrencilerinin GSM Operatör Tercihlerini Etkileyen Faktörlerin Analizi, Çukurova Üniversitesi Mühendislik Mimarlık Fakültesi Dergisi, 33(4): 203-212.

AYAZ, O., Alp, S. (2018). Saklı Markov Modeli Kullanılarak İstanbul'daki Üniversite Öğrencilerinin GSM Operatör Tercihlerini Etkileyen Faktörlerin Analizi, Çukurova Üniversitesi Mühendislik Mimarlık Fakültesi Dergisi, 33(4): 203-212.

BAYRAKDAROĞLU, A., Tepeli, Y. (2018). BİST Şehir Endekslerinin Risk-Getiri Analizi Üzerine Bir İnceleme, Muhasebe ve Finansman Dergisi, 80: 147-160.

BAYRAMOĞLU, M.F., Pekkaya, M. (2010). İMKB Tarafından Hesaplanan Endekslerde Yeni Gelişmeler ve İMKB Şehir Endeksleri, Muhasebe ve Finansman Dergisi (45): 200-215.

BHAR, R., Hamori, S. (2004). Hidden Markov Models Applications to Financial Economics, Netherlands: Kluwer Academiz Publishers.

BICEGO, M., Murino, V. (2004). Investigating Hidden Markov Models' Capabilities in 2D Shape Classification, IEEE Transactions On Pattern Analysis and Machine Intelligence, 26(2): 281-286.

CAN, T., Öz, E. (2009). Saklı Markov Modelleri Kullanılarak Türkiye’de Dolar Kurundaki Değişimin İncelenmesi, İstanbul Üniversitesi İşletme Fakültesi Dergisi, 1: 1-23.

CAN, T., Öz, E. (2009). Marka Tercihlerine ve Tercih Nedenlerine Gizli Markov Modelinin Uygulanması, Eskişehir Osmangazi Üniversitesi Sosyal Bilimler Dergisi, 10(2): 167-185.

CENTRAL BANK OF THE REPUBLIC OF TURKEY Web Page, https://evds2.tcmb.gov.tr/index.php?/ evds/serieMarket, (Access Date: 29.01.2019).

ÇAKIR, Z. (2016). Şehir Endekslerinin Finansal Performanslarının Ölçülmesi ve Değerlendirilmesi, (Yayımlanmamış Yüksek Lisans Tezi), Hitit Üniversitesi, Sosyal Bilimler Enstitüsü, Çorum.

DAĞLIOĞLU, C., Kıral, G. (2018). Hisse Senedi Piyasa Fiyatlarının Saklı Markov Modeli ile Tahmin Edilmesi, Uluslararası Ekonomi ve Yenilik Dergisi, 4(1): 61-75.

DUAN, J., Wang, W., Zeng, J., Zhang, D., Shi, B. (2009). A Prediction Algorithm for Time Series Based on Adaptive Model Selection, Expert Systems with Application, 36: 1308-1314.

GONZALES, A., San Roque, A., Garcia-Gonzales, J. (2005). Modeling and Forecasting Electricity Prices with Input/Output Hidden Markov Models, IEE Transactions on Power Systems, 20(1): 13-24.

HASSAN, M.R., Nath, B. (2005). Stock Market Forecasting Using Hidden Markov Model: A New Approach, 5th International Conference on Intelligent System Design and Application, Poland, 8-10 September.

HASSAN, M., Nath, B., Kirley, M. (2007). A Fusion Model of HMM, ANN and GA for Stock Market Forecasting, Expert Systems with Applications, 33(1): 171-180.

HASSAN, R. (2009). A Combination of Hidden Markov Model and Fuzzy Model for Stock Market Forecasting, Neurocomputing, 72: 3439-3446.

İSTANBUL STOCK EXCHANGE web page, http://www.borsaistanbul.com: http://www.borsaistanbul. com/data/Genelge/gn2013424.pdf, (Access Date: 29.01.2019). 
İLARSLAN, K. (2014). Hisse Senedi Fiyat Hareketlerinin Tahmin Edilmesinde Markov Zincirlerinin Kullanılması: İMKB 10 Bankacılık Endeksi İşletmeleri Üzerine Ampirik Bir Çalışma, Journal of Yasar University, 9(15): 6099-6260.

KARA, Y., Boyacıoğlu, M.A., Baykan, Ö.K. (2011). Predicting Direction of Stock Price Index Movement Using Artificial Neural Networks and Support Vector Machines: The Sample of the İstanbul Stock Exchange, Expert Systems with Applications, 38(5): 5311-5319.

KULA, V., \& Baykut, E. (2018). BİST Şehir Endekslerinin Volatilite Yapıları ve Rejim Değişimlerinin Analizi, Muhasebe ve Finans İncelemeleri Dergisi, 1(1): 38-59.

LÓPEZ-RUIZ, V.-R., Alfaro-Navarro, J.-L., Nevado-Peña, D. (2014). Knowledge-City Index Construction: An Intellectual Capital Perspective, Expert Systems with Applications, 41(12): 5560-5572.

LOU, H. (1995). Implementing the Viterbi Algorithm, IEEE Signal Processing Magazine, 12(5): 42-52.

NOOTYASKOOL, S., Choengtong, W. (2014). Hidden Markov Models Predict Foreign Exchange Rate, 14th International Symposium on Communications and Information Technologies (ISCIT), Incheon, 24-26 September.

ÖZ, E. (2009). İstanbul Menkul Kıymetler Borsası Üzerine Saklı Markov Modeli İle Bir Tahminleme, Ekonomik Yaklaşım, 20(72): 59-85.

RABINER, L. (1989). A Tutorial on Hidden Markov Models and Selected Applications in Speech Recognition, Proceedings of the IEEE, 77(2): 257-286.

SAUL, L., Jordan, M. (1995). Boltzmann Chains and Hidden Markov Models, Advances in Neural Information Processing Systems, 7: 435-442.

VASEGHI, S.V. (2007). Multimedia Signal Processing Theory and Applications in Speech, Music and Communications, England: John-Wiley \& Sons Ltd.

YAPRAKLI, S., Bozma, G., Akdağ, M. (2018). BİST Şehir Endekslerinde Oynaklığın Ölçülmesi: Alternatif Ekonometrik Modellerin Karşılaştırmalı Olarak İncelenmesi, Finans Politik \& Ekonomik Yorumlar, 639: 67-86. 


\section{Appendix 1: State Transition Probability Matrix $\left([A]_{15 \times \mathbf{1 5}}\right)$}

\begin{tabular}{|c|c|c|c|c|c|c|c|c|c|c|c|c|c|c|c|}
\hline $\begin{array}{l}S_{t} \backslash \\
S_{t+1}\end{array}$ & $S_{1}$ & $S_{2}$ & $S_{3}$ & $S_{4}$ & $S_{5}$ & $S_{6}$ & $\boldsymbol{S}_{7}$ & $S_{8}$ & $\boldsymbol{S}_{9}$ & $S_{10}$ & $S_{11}$ & $S_{12}$ & $S_{13}$ & $S_{14}$ & $S_{15}$ \\
\hline$S_{1}$ & 0,3333 & 0 & 0,1429 & 0,0952 & 0 & 0 & 0 & 0 & 0,1429 & 0 & 0,1429 & 0 & 0 & 0,1429 & 0 \\
\hline$S_{2}$ & 0 & 0,25 & 0,125 & 0 & 0,125 & 0,125 & 0 & 0 & 0 & 0,125 & 0 & 0 & 0,125 & 0 & 0,125 \\
\hline$S_{3}$ & 0,1429 & 0 & 0 & 0 & 0,1429 & 0 & 0 & 0 & 0,2857 & 0 & 0,2857 & 0,1429 & 0 & 0 & 0 \\
\hline$S_{4}$ & 0,5 & 0,5 & 0 & 0 & 0 & 0 & 0 & 0 & 0 & 0 & 0 & 0 & 0 & 0 & 0 \\
\hline$S_{5}$ & 0,2 & 0,05 & 0,1 & 0 & 0,2 & 0 & 0,15 & 0,05 & 0 & 0 & 0 & 0,15 & 0 & 0,1 & 0 \\
\hline$S_{6}$ & 0 & 0 & 0 & 0 & 0,5 & 0 & 0,5 & 0 & 0 & 0 & 0 & 0 & 0 & 0 & 0 \\
\hline $\boldsymbol{S}_{7}$ & 0,4 & 0 & 0 & 0 & 0,2 & 0,2 & 0 & 0 & 0,2 & 0 & 0 & 0 & 0 & 0 & 0 \\
\hline$S_{8}$ & 0,5 & 0 & 0 & 0 & 0 & 0 & 0 & 0 & 0,5 & 0 & 0 & 0 & 0 & 0 & 0 \\
\hline$S_{9}$ & 0 & 0,0909 & 0 & 0 & 0,1818 & 0 & 0 & 0 & 0,2727 & 0,0909 & 0,0909 & 0,1818 & 0 & 0,0909 & 0 \\
\hline$S_{10}$ & 0,3333 & 0 & 0,3333 & 0 & 0 & 0 & 0 & 0 & 0 & 0 & 0 & 0,3333 & 0 & 0 & 0 \\
\hline$S_{11}$ & 0,3333 & 0,1667 & 0 & 0 & 0 & 0 & 0 & 0 & 0 & 0,1667 & 0 & 0,1667 & 0 & 0,1667 & 0 \\
\hline$S_{12}$ & 0 & 0,1667 & 0,0833 & 0 & 0,3333 & 0 & 0 & 0 & 0,0833 & 0 & 0 & 0,0833 & 0,0833 & 0,1667 & 0 \\
\hline$S_{13}$ & 0 & 0 & 0 & 0 & 0,25 & 0 & 0 & 0 & 0 & 0 & 0 & 0,25 & 0,5 & 0 & 0 \\
\hline$S_{14}$ & 0,2 & 0 & 0 & 0 & 0,5 & 0 & 0 & 0,1 & 0 & 0 & 0 & 0,1 & 0 & 0,1 & 0 \\
\hline$S_{15}$ & 0 & 0 & 0 & 0 & 0 & 0 & 0 & 0 & 0 & 0 & 0 & 1 & 0 & 0 & 0 \\
\hline
\end{tabular}


Appendix 2: Observation Probability Distribution Matrix $\left([B]_{15 \times 2}\right)$

\begin{tabular}{l|ll}
$\boldsymbol{S}_{\boldsymbol{t}} \boldsymbol{G}_{\boldsymbol{t}}$ & $\boldsymbol{G}_{\mathbf{1}}$ & $\boldsymbol{G}_{\mathbf{2}}$ \\
\hline $\boldsymbol{S}_{\mathbf{1}}$ & 0,7619 & 0,2381 \\
$\boldsymbol{S}_{\mathbf{2}}$ & 0,125 & 0,875 \\
$\boldsymbol{S}_{\mathbf{3}}$ & 0,75 & 0,25 \\
$\boldsymbol{S}_{\mathbf{4}}$ & 0 & 1 \\
$\boldsymbol{S}_{\mathbf{5}}$ & 0,5 & 0,5 \\
$\boldsymbol{S}_{\mathbf{6}}$ & 0 & 1 \\
$\boldsymbol{S}_{\mathbf{7}}$ & 1 & 0 \\
$\boldsymbol{S}_{\mathbf{8}}$ & 0 & 1 \\
$\boldsymbol{S}_{\mathbf{9}}$ & 0,5454 & 0,4545 \\
$\boldsymbol{S}_{\mathbf{1 0}}$ & 0,3333 & 0,6667 \\
$\boldsymbol{S}_{\mathbf{1 1}}$ & 0,1666 & 0,8333 \\
$\boldsymbol{S}_{\mathbf{1 2}}$ & 0,75 & 0,25 \\
$\boldsymbol{S}_{\mathbf{1 3}}$ & 0,5 & 0,5 \\
$\boldsymbol{S}_{\mathbf{1 4}}$ & 0,4 & 0,6 \\
$\boldsymbol{S}_{\mathbf{1 5}}$ & 1 & 0
\end{tabular}

